\title{
Prevalence of Hepatitis C in Makurdi, North Central Nigeria
}

\author{
${ }^{1}$ Godwin .I. Achinge, ${ }^{1}$ Abraham .O. Malu, ${ }^{1}$ Peter T. Mbaave, ${ }^{2}$ Terkaa .T. Bitto, \\ ${ }^{3}$ Vivian .N. Shaahu, ${ }^{4}$ Hameed Mohammed, ${ }^{5}$ Michael A. Misauno \\ ${ }^{1}$ Department of Medicine, Benue State University Teaching Hospital, Makurdi, Nigeria \\ ${ }^{2}$ Riverside Specialist Clinic, Federal Medical Centre, Makurdi, Benue State, Nigeria \\ ${ }^{3}$ Department of Community Medicine, Federal Medical Centre, Makurdi, Nigeria \\ ${ }^{4}$ Department of Radiology, Benue State University Teaching Hospital, Makurdi, Nigeria \\ ${ }^{5}$ Department of Surgery, Jos University Teaching Hospital, Jos, Nigeria
}

\begin{abstract}
Background: This was a study to determine hepatitis $C$ sero-prevalence rate and create awareness on hepatitis $C$.

Methods: The study was a descriptive cross-sectional survey of attendees at the 2012, World Hepatitis Day ceremony at the Benue State University Teaching Hospital in Makurdi, Nigeria. Interviewer-administered questionnaires were used to obtain information from consenting participants. All respondents were screened for hepatitis $C$ using the Hepatitis C antibody (Anti HCV) test.

Results: Hepatitis $C$ sero-prevalence rate was 2.8\%. Most of the respondents were: aged 40 years or less (85\%), males (51.5\%), had 6-10 persons in their household (51.7\%). Only $6.4 \%$ had ever been transfused with blood, $4.3 \%$ had a history of jaundice, and $15.2 \%$ had a family member with hepatitis. Majority (85.1\%) had poor knowledge regarding hepatitis $C$ and only $27.4 \%$ had previously screened for it. There was no significant association between hepatitis $C$ sero-positive status with demographic, risk factors for hepatitis $C$ or knowledge about hepatitis $C$

Conclusions: Hepatitis $C$ infection is a health challenge in Nigeria in the setting of poor knowledge and inadequate screening facilities. All stakeholders should work towards improved awareness and testing for hepatitis $C$.

Key words: prevalence, hepatitis C Virus, Makurdi
\end{abstract}

\section{Introduction}

Hepatitis $\mathrm{C}$ virus (HCV), a relatively new virus discovered about 25 years ago has become a major cause of Chronic liver disease worldwide and the main reason for liver transplantation in the western world. ${ }^{1}$ In 2010, the member states of the World Health Organisation (WHO) at the Sixty-third World Health Assembly recognised Hepatitis C virus (HCV) as a growing public health threat. ${ }^{2}$ WHO estimates that $130-200$ million people, or $\sim 3 \%$ of the world's population, are living with chronic hepatitis C. ${ }^{2,3,4}$ These WHO's estimates are based on weighted averages for regions rather than individual countries since many countries lack data on HCV prevalence. The distribution of HCV infection varies in different parts of the world. The prevalence of HCV is less than $0.5 \%$ in the Scandinavia, 3.2\% in China, $4.8 \%$ in Pakistan and 22\% in Egypt. ${ }^{2.5}$ The high prevalence of $\mathrm{HCV}$ in Egypt is linked to the use of improperly sterilized glass syringes in a now-discontinued mass-treatment campaign for schistosomiasis. ${ }^{6}$

While there are no country wide surveys on the epidemiology of HCV In Nigeria, HCV prevalence appears to be increasing. ${ }^{7}$ Studies of HCV rates among blood donors in Nigeria show prevalence ranging from $5.4 \%$ in Makurdi, ${ }^{8} 8.4 \%$ in Lagos $^{9}$ to $12.3 \%$ in Benin city. ${ }^{10} \mathrm{HCV}$ rates among pregnant women in Nigeria appear to be lower ranging from $1.8-3.6 \%$ in Benin city, ${ }^{11,12} 4.3 \%$ in portharcourt, ${ }^{13} 4.5 \%$ in Kaduna ${ }^{14}$ to $4.7 \%$ in Enugu ${ }^{15}$.

A rising prevalence of $\mathrm{HCV}$ presents a peculiar challenge for the patient, the caregiver, the Government and the general public because the economic costs of hepatitis $\mathrm{C}$ have remained significantly high for the individual and the society and often beyond the reach of most people. In many countries, people are unable to afford treatment with antiviral drugs as they either lack insurance coverage or the insurance they have will not pay for antiviral drugs. ${ }^{16}$ Currently, $\mathrm{HCV}$ treatment is a combination of two expensive drugs, pegylated interferon and ribavirin. In recent times, highly expensive Directly Acting Antiviral agents (DAAs) have been licensed for use in the treatment of HCV genotype 1 which improves the chance of cure in these patients. For people who develop chronic forms of the disease, treatment is currently not readily available in the public healthcare system and unaffordable in the private sector. In Nigeria the cost of HCV treatment using pegylated interferon and Ribavirin is about two to three million naira. Adding a DAA would increase the cost a hundred fold. The persistently high cost of treatment for hepatitis $\mathrm{C}$ is generally attributed to the lack of political will to treat $\mathrm{HCV}$ among policymakers. Indeed, the absence of prevention efforts and the lack of political will among 
policymakers have remained two main obstacles to an effective HCV response in Nigeria and other parts of Africa.

WHO has been working in collaboration with other stakeholders towards raising awareness, promoting partnerships and mobilizing resources; providing evidence-based policy and data for action; prevention of transmission; and screening, care and treatment in an effort to prevent and control viral hepatitis. WHO has dedicated 28 July every year as World Hepatitis Day to increase awareness and understanding of viral hepatitis.

This study was carried out as part of activities marking the 2012 World Hepatitis Day in Makurdi with the aim of determining the prevalence of $\mathrm{HCV}$ and creating awareness on hepatitis $\mathrm{C}$ among participants in Benue State.

\section{Study design and scope}

\section{Methods}

The study was a descriptive cross-sectional survey of persons attending the 2012 World Hepatitis Day ceremony which held on the $28^{\text {th }}$ of July 2012 , at the Benue State University Teaching Hospital, Makurdi, Nigeria. A convenience sampling technique was used to recruit participants into the study after obtaining informed verbal consent.

\section{Measures}

A concise, interviewer-administered questionnaire was used to obtain information on: (1) Respondents' socio-demographic characteristics including age, gender, current employment status and number of persons per household. (2) Respondents' awareness of hepatitis C including a previous screening test. (3) Risk factors for hepatitis $\mathrm{C}$ infection including a history of blood transfusion and jaundice, and whether a family member was infected or not. (4) Respondents' knowledge of the modes of transmission of hepatitis C.

Knowledge of the modes of transmission of hepatitis $C$ was assessed on a four-item, three-point Likert scale. The four items were: (1) hepatitis C can be spread through blood; (2) hepatitis C can be spread through needle prick and sharp objects; (3) hepatitis $C$ can be spread through sexual intercourse; and (4) hepatitis C can be passed from mother-to-child. The Likert scale 3-point response categories were: "agree", "don't know", and "disagree", corresponding to scores of 3,2 and 1, respectively. The total knowledge score for each respondent was calculated by summing up his/her scores for the four items. The possible range of total knowledge scores were 12 (high), 8 (mid-point) and 4 (low). Since the mid-point was "don't know", the Likert scale was dichotomized to represent "good knowledge" and "poor knowledge" corresponding to scores of 12 and less than 12 , respectively.

All consenting participants were also screened for hepatitis $\mathrm{C}$ using the Hepatitis $\mathrm{C}$ antibody (Anti HCV) MICROPOINT Rapid Diagnostics tests kit and the results were privately disclosed to them. Those who tested positive were linked with the health care system for further management.

\section{Data analysis}

Data were entered into Microsoft Excel programme and imported into SPSS version 16 for analysis. The outcome variable was hepatitis $\mathrm{C}$ sero-status while the independent variables were socio-demographic characteristics, risk factors for hepatitis $\mathrm{C}$, and knowledge of hepatitis $\mathrm{C}$. Descriptive statistics were generated for each variable, including frequencies and percentages for categorical variables. Associations between variables were tested with chi-square; and multiple logistic regression was performed to identify factors predicting hepatitis $\mathrm{C}$ infection. Only variables associated with a $P$ value $<.10$ in bivariate analyses were considered eligible for inclusion in multiple logistic regression analysis. Level of statistical significance was set at $P<.05$. Cases were excluded if they were missing data required for specific analyses.

\section{Socio-demographic characteristics}

\section{Results}

Four hundred and fifteen people attended the 2012 World Hepatitis Day ceremonies in Makurdi. Out of these, $388(93.5 \%)$ consented to participate in the study. Within this study population, 11 respondents tested positive for hepatitis $\mathrm{C}$ antibodies, giving a sero-prevalence rate of $2.8 \%$. About three quarters $(75.8 \%)$ were aged 15-49 years, $75(19.3 \%)$ were $<15$ years of age and $19(4.9 \%)$ were $\geq 50$ years old. Two hundred $(51.5 \%)$ of the participants were males. One hundred and eighty three $(47.3 \%)$ of those tested were Civil servants, 148 (38.2\%) were students, $10(2.6 \%)$ were farmers, $20(5.2 \%)$ were traders and $26(6.7 \%)$ were unemployed. One hundred and seventy nine (46.5\%) of the participants were from households of 1-5 members, $199(51.7 \%)$ came from households with 6-10 members and 7 (1.8\%) did not know the number of persons in their households. (Table 1) 
Table 1: Socio-demographic characteristics

\begin{tabular}{lrr}
\hline $\begin{array}{l}\text { Socio-demographic } \\
\text { characteristics }\end{array}$ & Frequency & Percentage \\
\hline Age (years) & 75 & \\
$<15$ & 294 & 19.3 \\
$15-49$ & 19 & 75.8 \\
$\geq 50$ & & 4.9 \\
Gender & 200 & 51.5 \\
Male & 188 & 48.5 \\
Female & & \\
Occupation & 183 & 47.3 \\
Civil servant & 148 & 38.2 \\
Student & 10 & 2.6 \\
Farmer & 20 & 5.2 \\
Trader & 26 & 6.7 \\
Unemployed & & \\
Number of persons in house & & 46.5 \\
1-5 & 179 & 51.7 \\
6-10 & 199 & 1.8 \\
Don't know & 7 & \\
\hline
\end{tabular}

\section{Risk factors for and knowledge about hepatitis C infection}

Only $25(6.4 \%)$ respondents had a previous history of blood transfusion; 17 (4.3\%) reported a history of jaundice, while $59(15.2 \%)$ knew a family member who was infected with hepatitis. Majority $(85.1 \%)$ of the respondents had poor knowledge of the modes of transmission of hepatitis $\mathrm{C}$ and only about a quarter (27.4\%) had previously screened for it (Table 1).

\section{Associations between outcome and independent variables}

On bivariate analysis, a higher proportion of persons aged 40 years and above (3.4\%) were found to be hepatitis $C$ positive compared to persons aged 40 years and below (2.7\%), however, this was not statistically significant $(P=1.000)$. More males $(4.0 \%)$ tested positive for hepatitis $C$ compared to females $(1.6 \%)$ but the association was not statistically significant $(P=0.154)$. A higher proportion $(4.2 \%)$ of those employed tested positive for hepatitis $\mathrm{C}$ compared to the unemployed (1.1\%) but the association was not statistically significant $(P=0.133)$. A larger proportion of participants $(3.9 \%)$ who lived in a household of $1-5$ persons tested positive for hepatitis $\mathrm{C}$ compared to household of 6-10 persons (2.0\%) but the association was not statistically significant $(P=0.488)($ Table 2$)$.

Table 2: Association between socio-demographic characteristics and hepatitis $\mathrm{C}$ sero-status

\begin{tabular}{|c|c|c|c|c|}
\hline \multicolumn{5}{|c|}{ Hepatitis C sero-status } \\
\hline $\begin{array}{l}\text { Socio-demographic } \\
\text { characteristics }\end{array}$ & $\begin{array}{c}\text { Positive } \\
\text { n }(\%)\end{array}$ & $\begin{array}{l}\text { Negative } \\
\text { n }(\%)\end{array}$ & Test statistic & $P$-value \\
\hline \multicolumn{5}{|l|}{ Age (Years) } \\
\hline$\leq 40$ & $9(2.7)$ & $321(97.3)$ & Yate's continuity & 1.000 \\
\hline$>40$ & $2(3.4)$ & $56(96.6)$ & correction $=0.000$ & \\
\hline \multicolumn{5}{|l|}{ Gender } \\
\hline Male & $8(4.0)$ & $192(96.0)$ & $\chi^{2}=2.034$ & 0.154 \\
\hline Female & $3(1.6)$ & $185(98.4)$ & & \\
\hline \multicolumn{5}{|l|}{ Occupation } \\
\hline Employed & $9(4.2)$ & $204(95.8)$ & Yate's continuity & 0.133 \\
\hline Unemployed & $2(1.1)$ & $172(98.9)$ & correction $=2.262$ & \\
\hline \multicolumn{5}{|l|}{$\begin{array}{l}\text { Number of persons in } \\
\text { household }\end{array}$} \\
\hline $1-5$ persons & $7(3.9)$ & $172(96.1)$ & $\chi^{2}=1.436$ & 0.488 \\
\hline $6-10$ persons & $4(2.0)$ & $195(98.0)$ & & \\
\hline Don't know & $0(0.0)$ & $7(100.0)$ & & \\
\hline
\end{tabular}

Associations between risk factors for and knowledge about hepatitis $C$ infection and hepatitis $C$ sero-status 
There was no statistically significant association between hepatitis $C$ sero-positivity with previous blood transfusion $(\mathrm{P}=1.000)$, previous jaundice $(\mathrm{P}=1.000)$, family member with hepatitis $\mathrm{C}(\mathrm{P}=0.318)$, knowledge of hepatitis transmission $(\mathrm{P}=0.901)$ or prior hepatitis $\mathrm{C}$ screening $(\mathrm{P}=0.738)$. (Table 3)

Table 3: Association between risk factors for and knowledge about hepatitis $\mathrm{C}$ infection and hepatitis $\mathrm{C}$ sero-status

\begin{tabular}{|c|c|c|c|c|}
\hline \multicolumn{5}{|c|}{ Risk factors for hepatitis $C$} \\
\hline & \multicolumn{4}{|c|}{ Hepatitis C sero-status } \\
\hline & $\begin{array}{c}\text { Positive } \\
\text { n }(\%)\end{array}$ & $\begin{array}{c}\text { Negative } \\
n(\%)\end{array}$ & Test statistic & $P$-value \\
\hline \multicolumn{5}{|l|}{$\begin{array}{l}\text { History of blood } \\
\text { transfusion }\end{array}$} \\
\hline Yes & $1(4.0)$ & $24(96.0)$ & Yate's continuity & 1.000 \\
\hline No & $10(2.7)$ & $354(97.3)$ & correction $=<0.001$ & \\
\hline \multicolumn{5}{|l|}{ History of jaundice } \\
\hline Yes & $0(0.0)$ & $17(100.0)$ & Yate's continuity & 1.000 \\
\hline No & $11(3.0)$ & $361(97.0)$ & correction $=<0.001$ & \\
\hline \multicolumn{5}{|l|}{$\begin{array}{l}\text { Family member with } \\
\text { hepatitis C }\end{array}$} \\
\hline Yes & $0(0.0)$ & $59(100.0)$ & Yate's continuity & 0.318 \\
\hline No & $11(3.3)$ & $318(96.7)$ & correction $=0.998$ & \\
\hline \multicolumn{5}{|c|}{$\begin{array}{l}\text { Knowledge about hepatitis C } \\
\text { Knowledge of hepatitis } \\
\text { transmission }\end{array}$} \\
\hline Correct knowledge & $1(1.7)$ & $57(98.3)$ & Yate's continuity & 0.901 \\
\hline Incorrect knowledge & $10(3.0)$ & $320(97.0)$ & correction $=0.015$ & \\
\hline \multicolumn{5}{|c|}{ Prior hepatitis C screening } \\
\hline Yes & $4(3.8)$ & $102(96.2)$ & Yate's continuity & 0.738 \\
\hline No & $7(2.5)$ & $274(97.5)$ & correction $=0.112$ & \\
\hline
\end{tabular}

\section{Discussion}

Prevalence and Socio-demographic characteristics

The HCV sero-prevalence rate of $2.8 \%$ seen in this study is lower when compared to the $5.4 \%$ reported in an earlier study by Alao et $\mathrm{al}^{8}$ among blood donors in Makurdi.This varying reports from Makurdi are similar to the reports from Benin City where Onakewhor et $\mathrm{al}^{11}$ and ugbebor et al ${ }^{12}$ working independently, documented low HCV prevalence of $1.8 \%$ and $3.6 \%$ respectively among pregnant women in Benin City while Halim et $\mathrm{al}^{10}$ reported a high prevalence of $12.3 \%$ among blood donors in the same Benin city. Our findings suggest that the prevalence of $\mathrm{HCV}$ may vary even in the same geographical location however; the reasons for such variation may only be identified through further studies. The prevalence of HCV in our study was higher than the $0.4 \%$ reported by Mboto et al ${ }^{17}$ among pregnant women in Calabar. The low prevalence recorded in their study may be because their study subjects were exclusively females as it has been documented in several Nigerian cohorts that HCV prevalence among pregnant women appear lower compared to that of blood donors. ${ }^{11-15}$

\section{Risk factors for and knowledge about hepatitis $C$ infection}

Majority of the respondents in this study had poor knowledge of the modes of transmission of hepatitis C. Our finding is similar to that of Kabir et $\mathrm{al}^{18}$ who reported poor knowledge about hepatitis C in Iran. Only about a quarter of the participants had previously screened for hepatitis C implying that majority of Nigerians do not know their hepatitis $\mathrm{C}$ status further emphasizing the poor knowledge on hepatitis. This observation is particularly worrisome considering that screening of blood for HCV before transfusion is not always available especially for rural health facilities in Nigeria. Few of the respondents had previous history of blood transfusion and history of jaundice respectively; however, this was not significantly associated with HCV positivity. Finally, knowing a family member who was infected with hepatitis $\mathrm{C}$ was not significantly associated with $\mathrm{HCV}$ positivity.

\section{Associations between outcome and independent variables}

There was no significant association of HCV antibody sero-positivity with age, sex, family member with hepatitis $\mathrm{C}$ and a prior hepatitis $\mathrm{C}$ screening test. This finding is similar to that of Obienu et a ${ }^{15}$ and Mboto et $\mathrm{al}^{17}$ who did not identify significant risk factors to HCV in two independent Nigerian studies. 


\section{Conclusion}

Hepatitis $\mathrm{C}$ infection is a growing health challenge in Nigeria in the setting of poor knowledge, inadequate screening facilities, and expensive treatment. All stakeholders should work towards improved awareness, testing for hepatitis $\mathrm{C}$ and advocacy for affordable care.

\section{Acknowledgement}

Our profound gratitude goes to the Management of the Benue State University Teaching Hospital (BSUTH) for providing, the venue, Personnel, publicity and entertainment during the 2012 World Hepatitis Day ceremonies. We equally acknowledge Roche Pharmaceutical Company for providing the test kits that were used for screening during this activity.

\section{References}

[1]. Gravitz L. "A smouldering public-health crisis". Nature 2001; 474 (7350): S2-4.

[2]. World Health Organization (WHO). "Hepatitis C". June 2011.

[3]. W. H. O., "Global surveillance and control of hepatitis C. Report of a WHO consultation organized in collaboration with the Viral Hepatitis Prevention Board Antwerp, Belgium,"Journal of Viral Hepatitis. 1999;6: 35-47

[4]. Y. Hutin, M. E. Kitler, G. J. Dore et al., "Global burden of disease (GBD) for hepatitis C," Journal of Clinical Pharmacology. 2004; 44(1): 20-29

[5]. Fong T, Schoenfield L J, Hepatitis C. http://www.medicinenet.com/hepatitis c/article

[6]. Alter MJ. Epidemiology of hepatitis C virus infection. WJG 2007;13 (17): 2436-41

[7]. Ejiofor O S, Emechebe G O, Igwe W C, Ifeadike C O, Ubajaka C F. Hepatitis C virus infection in Nigerians. Niger Med J [serial online] 2010 [cited 2013 Apr 14];51:173-6. Available from: http://www.nigeriamedj.com/text.asp?2010/51/4/173/73290

[8]. Alao O, Okwori E, Araoye M: The Sero-Prevalence Of Hepatitis C Virus (HCV) Infection Among Prospective Blood Donors In Makurdi, Nigeria . The Internet Journal of Infectious Diseases. 2010 Volume 8 Number 1. DOI: 10.5580/1d2e

[9]. Ayolabi C. I, Taiwo M. A, Omilabu S. A, Abebisi A. O, Fatoba O. M. Sero-prevalence of hepatitis C virus among blood donors in Lagos, Nigeria. African Journal of Biotechnology Vol. 5 (20), pp. 1944-1946, 16 October 2006. Available online at http://www.academicjournals.org/AJB

[10]. Halim N. K. and Ajayi O. I. Risk Factors and sero- prevalence of Hepatitis C Antibody in Blood donors in Nigeria. East Afr Med J 2000; 77: 410-2.

[11]. Onakewhor JU, Okonofua FE. Seroprevalence of Hepatitis C viral antibodies in pregnancy in a tertiary health facility in Nigeria. Niger J Clin Pract. 2009;12(1):65-73.

[12]. Ugbebor O, Aigbirior M, Osazuwa F et al. The prevalence of hepatitis B and C viral infections among pregnant women. North Am J Med Sci 2011; 3: 238-241

[13]. Ojule AC, Akani CI, Opurum HC. Sero-prevalence of hepatitis C antibodies in pregnant women in Port Harcourt, Nigeria. Port Harcourt Medical Journal 2008; 3 (1): 55-61

[14]. Sheyin Z, Jatau E.D, Mamman A.I, Randawa A.J,Bigwan I.E. Detection of Hepatitis C virus amongst pregnant women, in Kaduna state, Nigeria. Wudpecker Journal of Medical Sciences 2012; 1(2): 012-015. Available online at http://www.wudpeckerresearchjournals.org

[15]. Obienu O, Nwokediuko S, Malu A, Lesi F. Risk Factors for Hepatitis C Virus Transmission Obscure in Nigerian Patients. Gastroenterology Research and Practice 2011; 939673, 4 pages

[16]. El Khoury EL, AC; Klimack, WK; Wallace, C; Razavi, H. "Economic burden of hepatitis C-associated diseases in the United States". Journal of Viral Hepatitis 2011;19 (3): 153-60

[17]. Mboto C. I, Andy I E, Eni O I, Jewell A P. Prevalence, Sociodemographic Characteristics and Risk Factors for Hepatitis C Infection among Pregnant Women in Calabar Municipality, Nigeria. Hepat Mon. 2010; 10(2): 116-120.

[18]. Kabir A, Tabatabaei SV, Khaleghi S, et al. Knowledge, Attitudes and Practice of Iranian Medical Specialists regarding Hepatitis B and C. Hepat Mon. 2010; 10(3): 176-182. 